\title{
Trophic niche similarity among sea trout Salmo trutta in central Norway investigated using different time-integrated trophic tracers
}

\author{
J. G. Davidsen ${ }^{1, *}$, R. Knudsen ${ }^{2}$, M. Power ${ }^{3}$, A. D. Sjursen ${ }^{1}$, L. Rønning ${ }^{1}$, K. Hårsaker ${ }^{1}$, \\ T. F. Næsje ${ }^{4}$, J. V. Arnekleiv ${ }^{1}$ \\ ${ }^{1}$ NTNU University Museum, Norwegian University of Science and Technology, 7491 Trondheim, Norway \\ ${ }^{2}$ Department of Arctic and Marine Biology, The Arctic University of Norway, 9037 Tromsø, Norway \\ ${ }^{3}$ Department of Biology, University of Waterloo, Waterloo, ON, N2L 3G1, Canada \\ ${ }^{4}$ Norwegian Institute for Nature Research, 7485 Trondheim, Norway
}

\begin{abstract}
From 2011 to 2013, anadromous brown trout Salmo trutta (213-730 mm, total body length, $L_{\mathrm{T}}$ ) were collected during or shortly after their marine feeding migration at 7 different localities in central Norway. The mean volume of stomach content (\%) of marine fish prey eaten by $S$. trutta captured in marine waters varied from 34 to $89 \%$. There was a high prevalence $(67-100 \%)$ for parasite groups potentially transmitted by marine prey fish (i.e. nematodes, cestodes and trematodes) at all sampling sites. There was a significant overlap in the signatures of both $\delta^{13} \mathrm{C}$ and $\delta^{15} \mathrm{~N}$ in the muscle tissue between the 7 groups of $S$. trutta; however, individual variation within groups was large. A strong positive relationship between $\delta^{13} \mathrm{C}$ and $L_{\mathrm{T}}$ indicated sizedependent niche selection, with smaller individuals feeding less on marine prey and more on brackish or freshwater invertebrates in the estuary. Short-term gut contents data and trophically transmitted parasites showed that all size groups were feeding on marine fish. However, an increased dependence upon marine prey fish by larger $S$. trutta was indicated by a strong positive relationship between $L_{\mathrm{T}}$ and $\delta^{15} \mathrm{~N}$. Similarities in $S$. trutta feeding and time-integrated trophic tracers (stable isotopes and parasites) across the 7 localities supports the general view that $S$. trutta feed within similar marine trophic niches. This similarity in feeding niche requirements may make $S$. trutta populations vulnerable to anthropogenic ecosystem perturbations which reduce the diversity of potential marine prey items.
\end{abstract}

KEY WORDS: Feeding ecology $\cdot$ Marine migration $\cdot$ Niche overlap $\cdot$ Brown trout $\cdot$ Stable isotope analyses $\cdot$ Trophically transmitted parasites $\cdot$ Stomach contents

\section{INTRODUCTION}

Anadromous brown trout Salmo trutta L., often termed sea trout, are widely distributed in the coastal waters of Europe (Elliott 1994, Klemetsen et al. 2003). Outside of the natural area for the species (e.g. New Zealand, Kerguelen Islands and Canada), anadromy is similarly observed in introduced S. trutta (Elliott 1994, Lecomte et al. 2013). By exploiting better feeding habitats, migration en-

${ }^{*}$ Corresponding author: jan.davidsen@ntnu.no ables individuals to attain higher growth rates, larger size-at-age and higher fecundity (Hendry et al. 2004), all of which may confer fitness benefits compared to animals that do not migrate. Migration, however, incurs costs which include the physiological costs of ionoregulatory adjustments for marine habitation and an increased mortality probability, e.g. owing to predation, parasitism and diseases during migration (Gross et al. 1988, Jonsson \& Jonsson 1993).

() The authors 2017. Open Access under Creative Commons by Attribution Licence. Use, distribution and reproduction are unrestricted. Authors and original publication must be credited. 
During the last several decades, the abundance of $S$. trutta has declined markedly in many regions (ICES 2013). As an example, with the exception of northernmost areas, catches in Norwegian rivers have declined by $24-77 \%$ during the last 20 yr (Anon. 2015). Recent findings from several other countries (e.g. England, Ireland and Sweden; ICES 2013) indicate similar declines. It has been hypothesised that declines are related to decreased sea survival caused by changes in food supply or increasing infection by the ectoparasitic salmon lice Lepeophtheirus salmonis Krøyer, 1838 (ICES 2013, Thorstad et al. 2015).

Anadromous S. trutta growth depends largely on the availability of marine prey (Nall 1930, Wootton 1998). Growth rates increase abruptly when anadromous salmonids move from fresh to salt water (Jonsson 1985), probably because of improved feeding opportunities which more than compensate for increases in the energy costs of ionic regulation (McKay \& Gjerde 1985). However, knowledge of the marine feeding ecology of $S$. trutta is limited (Rikardsen et al. 2006). This is because $S$. trutta are difficult to catch at sea and most feeding studies are based on small sample sizes (Knutsen et al. 2001). The few studies of $S$. trutta feeding that exist highlight the dietary use of marine prey, such as small fish and large crustaceans (Grønvik \& Klemetsen 1987, Elliot 1997, Knutsen et al. 2001, Rikardsen et al. 2007, Knudsen et al. 2011), and seasonal variability of the diet (Rikardsen et al. 2006). In addition, parasite studies have shown $S$. trutta to be infected by generalist parasite species transmitted via amphipods or small prey fish such as gadoids and herring (Hemmingsen \& Mackenzie 2001, Knudsen et al. 2011). Nonetheless, there is a paucity of information on general life history characteristics of $S$. trutta (Thorstad et al. 2016), including comparative regional analyses of differences in feeding habits.

In light of limited information on the marine diet of $S$. trutta, the aim of the present study was to describe the marine diets and associated trophic niches of $S$. trutta populations from central Norway. Trophic niches were analysed using stomach content analysis (Hyslop 1980) and 2 time-integrated trophic tracers: trophically transmitted parasites (Knudsen et al. 1996) and stable isotopes (Michener \& Kaufman 2007). The use of both tracers provided indirect measurements of long-term trophic behaviour and resource use and made it possible to increase sample sizes by analysing marine feeding ecology based on $S$. trutta captured in the sea and in rivers a short time after re-entry from marine feeding. As marine fish seem to be common prey for anadromous $S$. trutta, we hypothesised that $S$. trutta from different populations within a coastal area would have similar marine trophic niches. Further, we hypothesised $S$. trutta would display generalist diets at the population level, but specialized feeding at the individual level, due to size-related feeding preferences.

\section{MATERIALS AND METHODS}

\section{Study areas}

Salmo trutta was collected from 7 different localities in central Norway, ranging from the Rauma River $\left(62.55653^{\circ} \mathrm{N}, 7.68825^{\circ} \mathrm{E}\right)$ in the south to the Drevja River $\left(65.94587^{\circ} \mathrm{N}, 13.13526^{\circ} \mathrm{E}\right)$ in the north (Fig. 1). Localities differed in river catchment area (28-3119 $\left.\mathrm{km}^{2}\right)$, the length of the lower river available to anadromous fish (6-42 km), and their distances from the open sea (0-73 km; Table 1).

\section{Sampling of S. trutta and potential prey}

All sampling took place during June-September 2011-2013 (Table 1). In total, 258 S. trutta were obtained using different collection methods from 7 localities (5 rivers/river mouths and 2 fjords; Fig. 1, Table 1). Based on subsequent $\delta^{34} \mathrm{~S}$ analyses (see 'Stable isotope analyses'), 40 individuals were defined as resident trout (non-migratory) and were omitted from further analysis.

In the Drevja , Hundåla and Rauma Rivers, rotenone had been used previously to eradicate Gyrodactylus salaris from the watercourses. The aim of the treatment was to kill all carriers of the parasite in the river system. As a part of the programme, dead fish were collected and preserved frozen for future studies. Salmo trutta individuals from these water courses were randomly sampled from the central storage facility maintained by the Norwegian Veterinary Institute and used in the present study. The location at Agdenes was not connected to a specific river system and consisted of catches from several local river systems obtained from fish confined to the fjord area with 2 bag nets (mesh sizes 40 and $58 \mathrm{~mm}$ ) at a research facility located at the mouth of the Trondheim Fjord. In the Nidelva River and the Hopaelva River estuary, S. trutta were captured by local game fishers with rod and line, while individuals from the marine Hemnfjord site were captured by gillnets (mesh size $35 \mathrm{~mm}$ ). Total length $\left(L_{\mathrm{T}}, \mathrm{mm}\right)$ was measured from the tip of the snout to the tip of the longest 


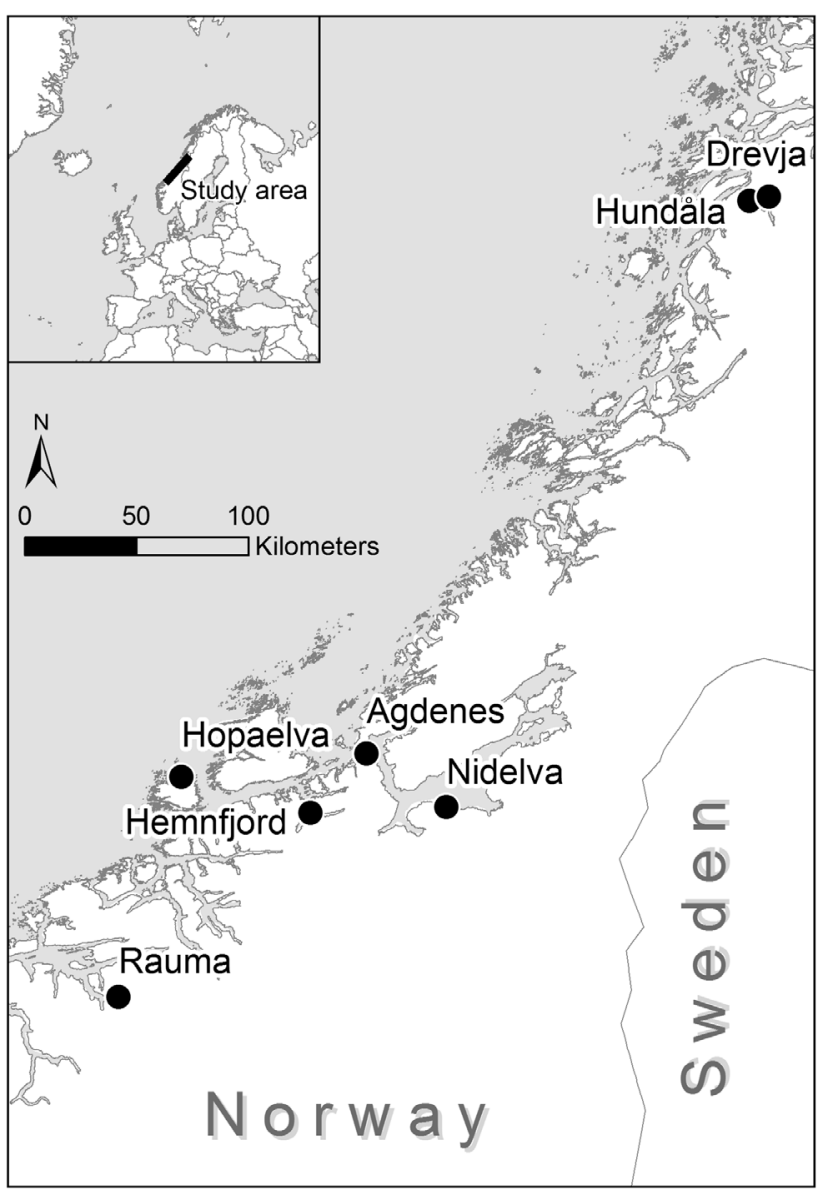

Fig. 1. Location of Salmo trutta sampling sites (2011-2013)

lobe of the caudal fin without compressing the lobes along the midline, and mass ( $g$ ) was obtained for all individuals. Differences in length and mass of fish between the sampling sites may partly be an artefact of sampling bias introduced by the different collection methods.

Potential prey species (e.g. forage fish and benthic invertebrates) were collected from June to September 2012 by trawling, gill netting and individual sampling in the marine Hemnfjord and then frozen.
The samples $(\mathrm{n}=40)$ included Gasterosteus aculeatus, Sprattus sprattus, Spinachia spinachia, Myoxocephalus scorpius, Gobiusculus flavescens, Clupea harengus, Scomber scombrus, Pleuronectiformes sp., Macrobrachium lanchesteri, Crangon crangon, Neomysis integer, Gammarus sp., Euphausiacea, Polychaeta and Mysida.

\section{Analyses of stomach contents}

A volumetric analysis of stomach contents was conducted following Hyslop (1980). Stomach contents from the upper end of the oesophagus to the pyloric sphincter were identified to the lowest practical taxonomic level (typically order or family) under a stereoscopic microscope. For most analyses, all orders and families were grouped into 'surface insects' or 'benthic invertebrates'. The relative importance of each prey category was evaluated as volume \% for each stomach and the total volume of food category taken by all sampled fish with stomach contents was given as a percentage of the total volume of each stomach content (Hyslop 1980). Gut contents continue to be degraded by stomach acid even if the fish is dead. Consequently, the difference between sampling sites in the ratio of empty stomachs may partly be a result of differences between time of death and gut content sampling at the different locations.

\section{Stable isotope analyses}

For stable isotope analyses $\left(\delta^{13} \mathrm{C}, \quad \delta^{15} \mathrm{~N}, \quad \delta^{34} \mathrm{~S}\right)$, a sample of dorsal muscle tissue (e.g. Pinnegar \& Polunin 1999) was dissected from all $S$. trutta and frozen until analysed. An exception was made with muscle tissue samples from the Hopaelva estuary which were preserved in $96 \%$ alcohol. Muscle tissue is commonly used to determine long-term diet, and in temperate and northern fish typically

Table 1. Overview of Salmo trutta sampling locations, 2011-2013. NA = no available information

\begin{tabular}{|c|c|c|c|c|c|c|}
\hline Location & $\begin{array}{l}\text { Catchment } \\
\text { area }\left(\mathrm{km}^{2}\right)\end{array}$ & $\begin{array}{l}\text { Length of anadro- } \\
\text { mous stretch (km) }\end{array}$ & $\begin{array}{c}\text { Distance to } \\
\text { open sea }(\mathrm{km})\end{array}$ & $\begin{array}{l}\text { Sampling place (fresh } \\
\text { water/marine water) }\end{array}$ & $\begin{array}{l}\text { Sampling } \\
\text { time }\end{array}$ & $\begin{array}{l}\text { Sampling } \\
\text { method }\end{array}$ \\
\hline Drevja River & 178 & 25 & 67 & River & Aug 2011 & Rotenone \\
\hline Hundåla River & 39 & 6 & 58 & River & Aug 2011 & Rotenone \\
\hline Nidelva River & 3119 & 8 & 73 & River & Jun-Sep 2011/2012 & Rod and line \\
\hline Agdenes & NA & NA & 0 & Marine & Jun-Aug 2012 & Bag net \\
\hline Hemnfjord & NA & NA & 30 & Marine & Jun-Sep 2012 & Gillnet \\
\hline Hopaelva estuary & 28 & 10 & 4 & Estuary & Jul-Sep 2012 & Fly fishing \\
\hline Rauma River & 1240 & 42 & 72 & River & Aug 2013 & Rotenone \\
\hline
\end{tabular}


reflects the summer period of somatic growth, with the tissue turnover of muscle depending on growth rate (Trueman et al. 2005). For rapidly growing salmonid fishes, the isotopic value of muscle will equilibrate to diet within the order of a few months (Perga \& Gerdeaux 2005, Trueman et al. 2005, Phillips \& Eldridge 2006). As a consequence, muscle tissue is considered a useful surrogate for the study of temporally integrated feeding in anadromous salmonid fishes (Doucett et al. 1999b, Etheridge et al. 2008, van der Velden et al. 2012), with $\delta^{13} \mathrm{C}$ and $\delta^{15} \mathrm{~N}$ stable isotope ratios of a consumer reflecting the isotopic signatures of the prey consumed during the time period that the tissue was synthesised (Fry 2006). The $\delta^{13} \mathrm{C}$ signature provides an indication of the origin of the carbon source since littoral, pelagic and profundal carbon sources in freshwater have different $\delta^{13} \mathrm{C}$ signatures, decreasing along littoralprofundal gradients (Van der Zanden \& Rasmussen 1999). In the marine environment, the $\delta^{13} \mathrm{C}$ value of marine carbonates (dissolved inorganic carbon) tends toward $0 \%$ with the result that the $\delta^{13} \mathrm{C}$ of resident biota are also elevated (Sharp 2007). In contrast, the $\delta^{15} \mathrm{~N}$ signature of an organism indicates trophic position, since $\delta^{15} \mathrm{~N}$ signatures increase with an increase in trophic level (Van der Zanden \& Rasmussen 1999, Post 2002). Further, the stable signature ratio of $\delta^{34} \mathrm{~S}$ reflects whether individuals have previously been to sea (Doucett et al. 1999a), and coupled with $\delta^{13} \mathrm{C}$, may be used to screen organisms for marine residency.

Here, we sorted captured fish into anadromous and non-anadromous groupings based initially on their $\delta^{13} \mathrm{C}$ value, with all fish having $\delta^{13} \mathrm{C}$ values $>-22 \%$ being treated as anadromous given that $\delta^{13} \mathrm{C}=-22 \%$ is the lower $\delta^{13} \mathrm{C}$ limit for marine organisms found in central Norwegian coastal waters (Fredriksen 2003). The criterion was considered conservative and likely to result in the inclusion of both anadromous and non-anadromous fish in a single group. Accordingly, fish with $\delta^{13} \mathrm{C}$ values $<-22 \%$ were re-analysed using $\delta^{34} \mathrm{~S}$ to more precisely establish anadromy, with higher $\delta^{34} \mathrm{~S}$ values $(>10 \%$ ) being considered indicative of anadromy (Doucett et al. 1999a).

Tissues from both $S$. trutta and potential prey were dried at $50^{\circ} \mathrm{C}$ for $24 \mathrm{~h}$. At the University of Waterloo, Canada, the dried tissue was grounded to a fine powder with a mortar and pestle and analysed for stable isotope ratios $\left(\delta^{13} \mathrm{C}, \delta^{15} \mathrm{~N}, \delta^{34} \mathrm{~S}\right)$ using the methods described by Guiguer et al. (2002), Power et al. (2009) and van der Velden et al. (2012). Analyses for $\delta^{13} \mathrm{C}$ and $\delta^{15} \mathrm{~N}$ were performed using a Delta Plus Continuous Flow Stable Isotope Ratio Mass Spectrometer
(Thermo Finnigan) coupled to a Carlo Erba Elemental Analyzer (CHNS-O EA1108, Carlo Erba). Analysis of $\delta^{34} \mathrm{~S}$ was completed using an Isochrom Continuous Flow Stable Isotope Ratio Mass Spectrometer (GV Instruments, Micromass) coupled to a Costech Elemental Analyzer (CNSO 4010, Costech Analytical Technologies). Working internal laboratory standards were calibrated against the International Atomic Energy Agency standards CH6 for carbon, $\mathrm{N} 1$ and N2 for nitrogen, and SO-5, S1 and S2 for sulphur and were run as controls throughout the analysis to ensure the continued accuracy of all measurements $( \pm 0.2 \%$ for carbon, $\pm 0.3 \%$ o for nitrogen and $\pm 0.5 \%$ for sulphur in an organic material). Analytical precision was assessed by mean differences of 1 in 10 duplicate samples, where the mean \pm SD was $0.14 \pm$ $0.2 \%$ for $\delta^{13} \mathrm{C}$ and $0.18 \pm 0.2 \%$ for $\delta^{15} \mathrm{~N}$. All results were expressed in standard $\delta$ notation (Perga \& Gerdeaux 2005).

The C:N ratios of studied fish were uniformly low (C:N $<4$ in $94 \%$ of samples), which suggests carbon isotope signatures can be left uncorrected for lipids (e.g. Post et al. 2007, Jardine et al. 2013). Use of this rule is unlikely to bias analytical results as individuals with C:N > 4 were drawn from 6 of the studied populations and from sizes in the range of 272-730 mm. Furthermore, as noted by Fagan et al. (2011), arbitrary use of lipid correction is itself questionable, given the demonstrated lack of relationship between lipid-corrected values and actual measured lipid levels in fish. Given the limited need for lipid correction based on the $<4$ rule, the random occurrence of individuals with a high $\mathrm{C}: \mathrm{N}$ ratio within and among populations and the published evidence questioning the use of routine lipid correction in fish ecological studies, the bulk carbon isotope values used in this study were not lipid-corrected.

The need for baseline adjustments was assessed using 1-way ANOVA followed by Tukey's post-hoc honestly significant difference test (e.g. Zar 2009). Such an approach works well if the $\delta^{15} \mathrm{~N}$ values of the assumed primary consumers are near $0 \%$ (e.g. Hobson et al. 2002, Jennings \& Warr 2003, Søreide et al. $2006)$, as they were here. Stable isotope data $\left(\delta^{15} \mathrm{~N}\right)$ for available lower trophic level (e.g. Amphipoda, Mysida, Mytilus edulis) invertebrates sampled from across the latitudinal range $62.3-63.3^{\circ} \mathrm{N}$ along the central Norwegian coastal area proximate to the $S$. trutta sampling sites were not significantly different (ANOVA, $F_{2,30}=2.566, \mathrm{p}=0.094$ ). Although the tested range encompassed only a portion of the range for which $S$. trutta samples were available $\left(63.0-65.3^{\circ} \mathrm{N}\right)$, the data available for testing did not support the use 
of baseline adjustments for among site comparisons of $S$. trutta stable isotope data. Accordingly, no adjustments were made.

\section{Analyses of trophically transmitted parasites}

Marine parasites of $S$. trutta were recorded and enumerated from the available frozen intestine and stomach of individual fish as a standard method. Based on a salmonid study from a northern Norwegian fjord system (see Knudsen et al. 2011), parasites were divided into 2 groups according to their intermediate host type (MacKenzie \& Abaunza 1998): (1) parasites transmitted by gammarids, such as the acanthocephalan Echinorhyncus gadi (Zoega, 1776), and (2) parasites transmitted mainly by marine fish, such as trematodes (e.g. Lecithaster gibbosus Rudolphi, 1802 and Derogenes varicus Müller, 1784), and several nematode species and adult cestodes (Eubothrium sp. Nybelin, 1922). The terms 'prevalence' (i.e. the proportion of infected hosts) and 'abundance' (i.e. the mean number of parasites in both infected and uninfected hosts) sensu Bush et al. (1997) were used here to describe parasite occurrences in S. trutta.

\section{Data analyses}

Prey $\delta^{15} \mathrm{~N}$ and $\delta^{13} \mathrm{C}$ signatures were corrected for trophic enrichment $(\Delta)$ using, respectively, mean fractionation factors of 3.23 and 1.03, and are presented as post-fractionation equivalents (plotted prey $\delta$ values $=$ prey isotope values $+\Delta$ ) when compared or plotted with $S$. trutta stable isotope values (e.g. Jensen et al. 2012).

The SIBER package (Stable Isotope Bayesian Ellipses in R, version 2.0.3, Jackson \& Parnell 2016) was used to study isotopic niche widths. Preservation of muscle tissue in $96 \%$ alcohol may influence $\delta^{15} \mathrm{~N}$ and $\delta^{13} \mathrm{C}$ signatures and confound correlations with signatures from frozen material (Stallings et al. 2015). Consequently, the samples from the Hopaelva estuary were omitted from the analyses of isotopic niche widths.

To analyse if either $\delta^{13} \mathrm{C}$ or $\delta^{15} \mathrm{~N}$ were dependent on the fish $L_{\mathrm{T}}$, a general linear model (GLM) with a Gaussian error distribution and identity link function were used. Collection site was included as a grouping variable to compare the strength of ontogenetic shifts among populations. The possible relationship between $L_{\mathrm{T}}$ and the tendency to be piscivorous was tested by a binomial logistic regression model using the logit link. All statistical analyses were conducted using RStudio version 1.0.44 (www. rstudio.com).

\section{RESULTS}

From 258 Salmo trutta from the 7 locations (Fig. 1), 218 individuals (213-730 $\mathrm{mm} L_{\mathrm{T}}$, Table 2) were identified as being anadromous using stable isotope data. The samples from the Rauma River had the largest mean $L_{\mathrm{T}}$ and mass (599 mm, $2292 \mathrm{~g}$ ), while $S$. trutta with the smallest mean $L_{\mathrm{T}}$ and mass were from the Drevja River (313 mm, 364 g).

\section{Stomach contents}

S. trutta captured in marine waters (Agdenes, Hemnfjord and Hopaelva estuary) in general had higher amounts of marine fish in their stomachs than individuals sampled in the rivers. The mean volume (\%) of prey fish in individuals captured in the Hopaelva estuary and in the Agdenes bag nets in the

Table 2. Number of sampled anadromous Salmo trutta (n), total body length, mass and proportion of empty stomachs from 7 study sampling localities in central Norway

\begin{tabular}{|c|c|c|c|c|c|c|}
\hline \multirow[t]{2}{*}{ Location } & \multirow[t]{2}{*}{$\mathrm{n}$} & \multicolumn{2}{|c|}{ Total body length (mm) } & \multicolumn{2}{|c|}{$\longrightarrow$ Mass (g) } & \multirow{2}{*}{$\begin{array}{c}\text { Empty } \\
\text { stomachs (\%) }\end{array}$} \\
\hline & & Mean (SD) & Range & Mean (SD) & Range & \\
\hline Drevja River & 28 & $316(62)$ & $218-442$ & $364(196)$ & $117-817$ & 82 \\
\hline Hundåla River & 80 & $367(80)$ & $213-583$ & 553 (352) & $120-1970$ & 81 \\
\hline Nidelva River & $6\left(4^{\mathrm{a}}\right)$ & $522(167)$ & $347-730$ & $1817(1808)$ & $356-4200$ & 100 \\
\hline Agdenes & 37 & $433(77)$ & $346-660$ & $966(662)$ & $427-3150$ & 76 \\
\hline Hemnfjord & 32 & $356(72)$ & $235-495$ & $475(252)$ & $130-1184$ & 50 \\
\hline Hopaelva estuary & 21 & $369(85)$ & $262-600$ & $606(367)$ & $186-1700$ & 33 \\
\hline Rauma River & 14 & $599(82)$ & $485-730$ & $2292(893)$ & $1077-4030$ & 21 \\
\hline
\end{tabular}




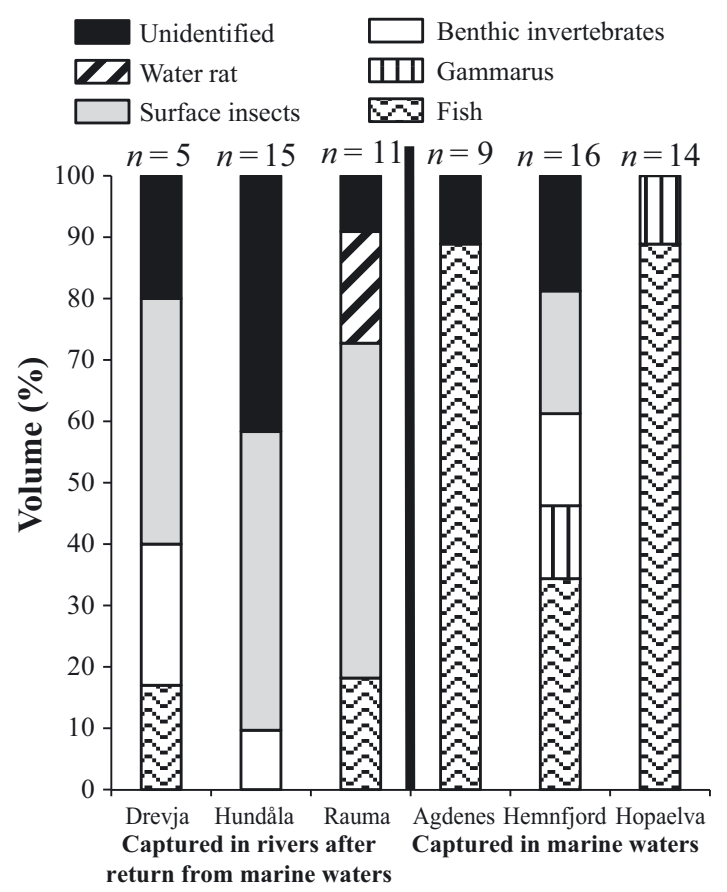

Fig. 2. Prey species composition in stomach contents of Salmo trutta taken from 6 different localities in central Norway. Samples are from marine waters and from rivers after return from marine waters. Benthic invertebrates: Plecoptera, Trichoptera, Simulidae, Chironomidae, Megaloptera, Hydracarina, Oligochaeta, Lymnidae, Planorbidae, Nematoda, Odonata. Surface insects include all stages (larvae, pupea, adult) of insects from the terrestrial environment and aquatic adult insects with an aerial life stage. Water rat: Arvicola amphibiu. In Nidelva River (not shown) all sampled stomachs were empty

fjord was $89 \%$ (Fig. 2). Marine-captured S. trutta from Hemnfjord averaged $34 \%$, while individuals sampled in the rivers after the marine feeding migration never had more than $18 \%$ fish content in the stomach. Instead, most of the identified stomach contents consisted of benthic invertebrates and surface insects (Fig. 2). Identified marine fish prey consisted of the pelagic fish species sprat Sprattus sprattus L., herring Clupea harengus L. and small sandeel Ammodytes tobianus L. The proportion of empty stomachs (Table 2) ranged from $21 \%$ (Rauma River, $\mathrm{n}=14$ ) to $100 \%$ (Nidelva River, $\mathrm{n}=6$ ).

The prey fish described above were found in the stomach contents of all 3 size groups (Fig. 3), and there was no increase in the percent fish content with size $\left(r^{2}=0.004, n=70, p>0.05\right)$. Surface insects were found in all length classes, and there was no correlation between percent volume and size of the $S$. trutta $\left(\mathrm{r}^{2}=0.0006, \mathrm{n}=70, \mathrm{p}>0.05\right)$. Gammarus spp. were found only in fish $>300 \mathrm{~mm}$.

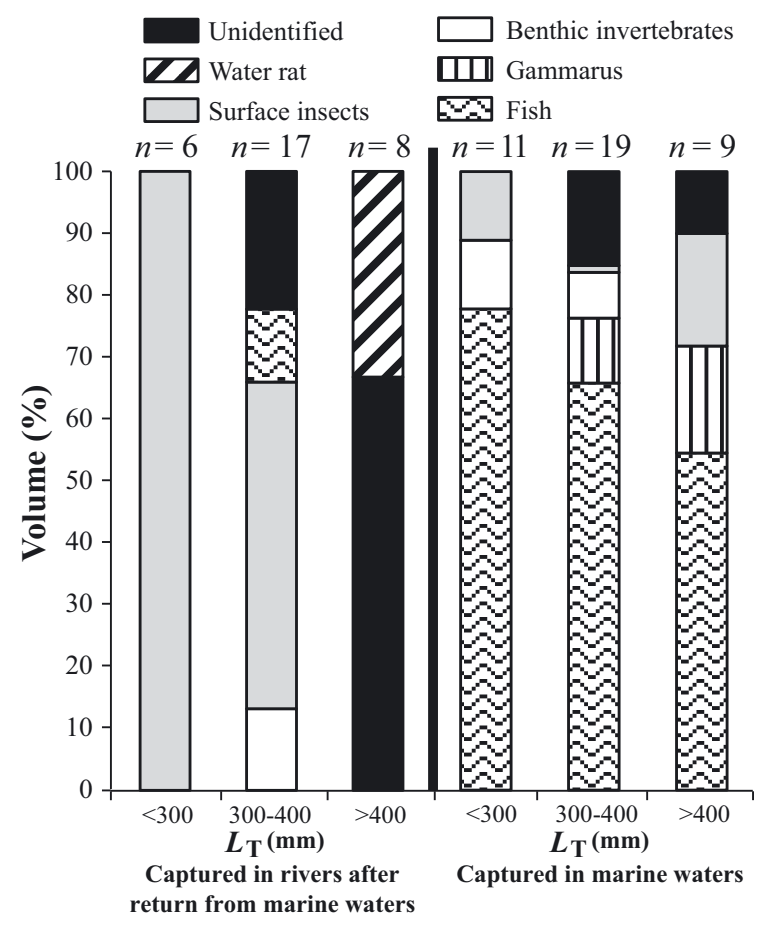

Fig. 3. Prey species composition in stomach contents of Salmo trutta taken from 6 localities in central Norway according to mean total boldy length $\left(L_{\mathrm{T}}\right)$. See Fig. 2 for details of prey groups

\section{Stable isotope signatures}

There was a large overlap in the SIBER ellipses between $S$. trutta from the 6 localities (Fig. 4), with a number of the ellipses for populations being wholly contained in the ellipses of other populations. In total, $90 \%$ of the $S$. trutta had values for $\delta^{13} \mathrm{C}$ and $\delta^{15} \mathrm{~N}$ within the ranges of -18.7 to $-25.2 \%$ and 7.9 to $14.5 \%$, respectively. The $\delta^{13} \mathrm{C}$ and $\delta^{15} \mathrm{~N}$ signatures from $S$. trutta and their potential prey in the marine Hemnfjord indicated that they had mainly been feeding on krill and pelagic marine fishes (Fig. 5).

Overall, there was an increase in the $\delta^{13} \mathrm{C}$ signature (GLM, $\mathrm{n}=197, F=36.179, \mathrm{p}<0.001)$ and $\delta^{15} \mathrm{~N}$ signature $(\mathrm{n}=197, F=94.102, \mathrm{p}<0.001)$ with increasing $L_{\mathrm{T}}$. The strength of the correlation differed between collection sites $\left(\delta^{13} \mathrm{C}\right.$ signature: $\mathrm{n}=7, F=9.843, \mathrm{p}<$ $0.001 ; \delta^{15} \mathrm{~N}$ signature: $\left.\mathrm{n}=7, F=33.609, \mathrm{p}=0.002\right) . S$. trutta from Agdenes and the Rauma River did not show any relationship between $\delta^{13} \mathrm{C}$ and $L_{\mathrm{T}}$ (Agdenes: $\mathrm{n}=37, F=2.763, \mathrm{p}=0.11$; Rauma River: $\mathrm{n}=14, \mathrm{~F}=0.491, \mathrm{p}>0.05$ ), while $S$. trutta from the Drevja and Nidelva Rivers did not show any relationship between $\delta^{13} \mathrm{C}$ or $\delta^{15} \mathrm{~N}$ signatures and $L_{\mathrm{T}}\left(\delta^{13} \mathrm{C}\right.$ : 


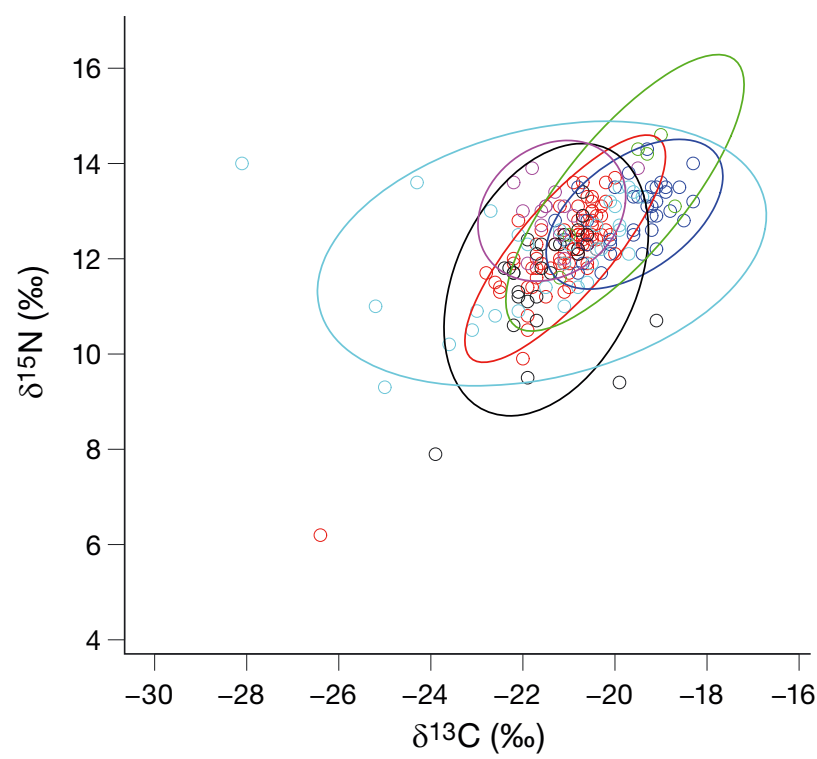

Fig. 4. Standard ellipse area for Salmo trutta from 6 different localities in central Norway. (Black) Drevja River; (red) Hundåla River; (green) Nidelva River; (dark blue) Agdenes; (light blue) Hemnfjord; (pink) Rauma River

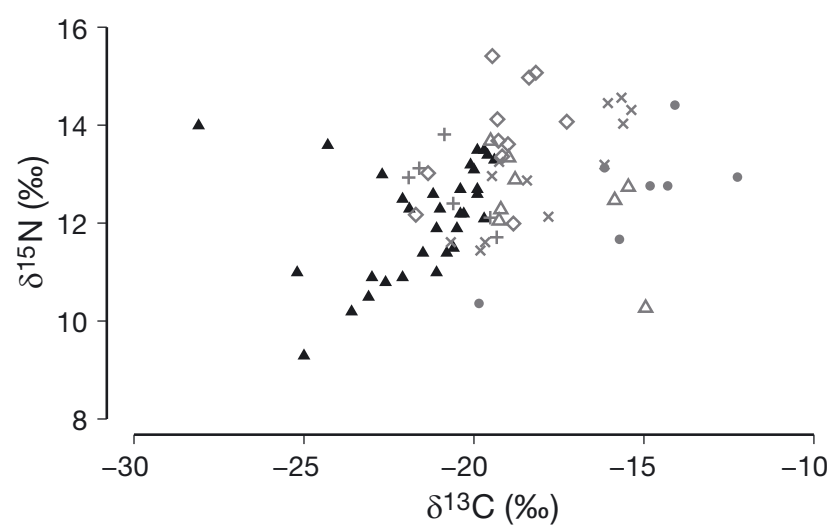

Fig. 5. Stable isotope signatures of Salmo trutta and their potential prey from Hemnfjord in central Norway. (ム) $S$. trutta; $(\times)$ littoral marine fish; $(\diamond)$ pelagic marine fish; $(+) \mathrm{krill}_{;}(\bullet)$ bristle worm; $(\Delta)$ shrimp. Note that prey isotope signatures have been corrected for fractionation and are plotted as post-fractionation values (i.e. measured isotope value + fractionation factor)
Drevja: $\mathrm{n}=28, F=1.416, \mathrm{p}>0.05$; Nidelva: $\mathrm{n}=6, F=$ $0.759, \mathrm{p}>0.05$; and $\delta^{15} \mathrm{~N}$ : Drevja: $\mathrm{n}=28, F=0.592, \mathrm{p}>$ 0.05; Nidelva: $\mathrm{n}=6, F=4.609, \mathrm{p}>0.05)$.

\section{Composition of trophically transmitted parasites}

There was a high prevalence (67-100\%) of the parasite groups potentially transmitted by marine fish as prey at all sampling sites, for $S$. trutta caught both in the river and in the sea (Table 3). Cestodes, mainly marine Eubothrium sp., were the most prevalent (45-92\%). Trematodes varied more (8-80\%) and nematodes ranged from no infection (river samples from Rauma) up to $54 \%$ (marine samples from Agdenes). The abundance of parasite groups potentially transmitted by fish was low to intermediate and varied from 1.8 (river samples from the Hundåla River) up to 13.3 (marine samples from the Hopaelva estuary). However, there were no differences in levels of prevalence ( $t$-test; $\mathrm{n}=8, \mathrm{p}>0.05)$ or abundance $(\mathrm{n}=$ $8, \mathrm{p}>0.05)$ between individuals captured in marine water or freshwater. The infection level of Acanthocephala, which have marine crustaceans as an intermediate host, was generally low as indicated by prevalence (highest 15\% in Drevja River samples) and abundance (highest 1.4 in marine samples from Hemnfjord). The smallest piscivorous $S$. trutta was $213 \mathrm{~mm}$ based on the abundance of parasite groups potentially transmitted by fish. There was no relationship between $L_{\mathrm{T}}$ and the tendency to be a piscivore (logistic regression, $\mathrm{n}=156, \mathrm{p}>0.05$ ) based on stomach content or trophically transmitted parasites.

\section{DISCUSSION}

This study documented the regional similarity of Salmo trutta population marine trophic niches as

Table 3. Infection of marine parasites in Salmo trutta caught in riverine (R) and marine (M) environments. Fish-par denotes combined parasite groups (Nematodes, Cestodes and Trematodes) that can be potentially transmitted by fish as prey. $\operatorname{Pr}=$ prevalence $(\%) ; \mathrm{Ab}=$ abundance $(\%)$

\begin{tabular}{|c|c|c|c|c|c|c|c|c|c|c|c|c|}
\hline \multirow{2}{*}{ Locality } & \multirow{2}{*}{ Habitat } & \multirow[t]{2}{*}{$\mathrm{n}$} & \multicolumn{2}{|c|}{ Achanthocephala } & \multicolumn{2}{|c|}{ Nematodes } & \multicolumn{2}{|c|}{ Cestodes } & \multicolumn{2}{|c|}{ Trematodes } & \multicolumn{2}{|c|}{ Fish-par } \\
\hline & & & $\operatorname{Pr}$ & $\mathrm{Ab}$ & $\operatorname{Pr}$ & $\mathrm{Ab}$ & $\operatorname{Pr}$ & $\mathrm{Ab}$ & $\operatorname{Pr}$ & $\mathrm{Ab}$ & $\operatorname{Pr}$ & $\mathrm{Ab}$ \\
\hline Drevja River & $\mathrm{R}$ & 20 & 15.0 & 0.7 & 35 & 2.5 & 45.0 & 1.3 & 20.0 & 0.4 & 85.0 & 4.2 \\
\hline Hundåla River & $\mathrm{R}$ & 44 & 4.6 & 0.1 & 15.9 & 0.2 & 63.6 & 1.1 & 29.5 & 0.5 & 77.3 & 1.8 \\
\hline Nidelva River & $\mathrm{R}$ & 3 & 0.0 & 0.0 & 0.0 & 0.0 & 66.7 & 5.0 & 33.3 & 2.3 & 66.7 & 7.3 \\
\hline Rauma River & $\mathrm{R}$ & 12 & 0.0 & 0.0 & 0.0 & 0.0 & 91.7 & 8.8 & 8.3 & 0.3 & 100 & 9.1 \\
\hline Agdenes & M & 28 & 3.6 & 0.4 & 53.6 & 1.8 & 50.0 & 1.0 & 35.7 & 0.9 & 75.0 & 3.7 \\
\hline Hemnfjord & M & 29 & 3.5 & 1.4 & 34.9 & 0.7 & 58.6 & 2.6 & 17.2 & 1.1 & 79.3 & 4.4 \\
\hline Hopaelva estuary & y $\mathrm{M}$ & 20 & 0.0 & 0.0 & 25.0 & 0.6 & 85.0 & 3.4 & 80.0 & 9.3 & 100 & 13.3 \\
\hline
\end{tabular}


measured by stable isotope and marine parasite tracers along a $400 \mathrm{~km}$ coastal area of central Norway. Stomach contents from individuals that were caught in marine water consisted mainly of marine fish, while the stomachs of individuals captured in the rivers had higher abundances of benthic invertebrates and surface insects. The abundance and prevalence of parasite groups potentially transmitted by marine fish did not differ between individuals captured in marine water or in the rivers, indicating that $S$. trutta captured in the river had also been mainly feeding on marine fish sometime prior to their capture. Likewise, stable isotope analyses confirmed similar resource utilisation across the sea-migratory populations. Our study indicated a diverse, habitatspecific diet of $S$. trutta which concurs with earlier characterisations of $S$. trutta as an opportunistic feeder (Pemberton 1976, Knutsen et al. 2001, Rikardsen et al. 2006), although there is an apparent preference and reliance on smaller pelagic fishes during their marine feeding migration.

Analyses of stomach contents showed that $S$. trutta feed on a variety of prey items, but fish were the dominant prey found in individuals captured in marine waters (Agdenes, Hemnfjord and Hopaelva estuary). Reliance on fish as prey has also been documented in earlier studies of $S$. trutta diets (Grønvik \& Klemetsen 1987, Knutsen et al. 2001, Knudsen et al. 2011), and for other coastal feeding anadromous salmonids such as Arctic charr Salvelinus alpinus (L.) (Klemetsen et al. 2003, Rikardsen \& Dempson 2011) and Atlantic salmon Salmo salar (Renkawitz et al. 2015). The occurrence of surface insects and benthic invertebrates in stomachs from $S$. trutta sampled in the rivers after the marine feeding migration indicates that these $S$. trutta also feed in the river mouth or in the river after returning from the sea.

Stable isotope analysis of muscle tissue from the $S$. trutta in this study revealed a broad range of signatures for both $\delta^{13} \mathrm{C}$ and $\delta^{15} \mathrm{~N}$, although the values tended toward the higher values indicative of marine feeding (e.g. Doucett et al. 1999a, Etheridge et al. 2008). The range of $\delta^{13} \mathrm{C}$ indicates that the $S$. trutta have a mixed feeding strategy, with comparison of stable isotope signatures from $S$. trutta and their potential prey in Hemnfjord indicating mixed feeding on krill, and pelagic and littoral fishes. Individuals with $\delta^{13} \mathrm{C}$ values in the range of -21 to $-22 \%$ may only have fed for a short time in the marine habitat or may have mainly preyed upon brackish or freshwater invertebrates in the estuary (Etheridge et al. 2008). While the majority of stable isotope signatures are consistent with marine feeding, differences were evi- dent in the stomach content analyses among sites. These results suggest rapid transition from fish to invertebrate prey as $S$. trutta re-enter freshwater. Lags in tissue turnover in salmonids are typically on the order of months (Trueman et al. 2005), implying that despite evidence of recent freshwater feeding and residency, the majority of piscivorous $S$. trutta sampled in this study fed in the marine environment.

The observed relationship between $L_{\mathrm{T}}$ and $\delta^{15} \mathrm{~N}$ is indicative of size-dependent feeding strategies, with smaller $S$. trutta feeding on a mixture of invertebrate and fish prey in estuaries and larger $S$. trutta feeding mainly on marine prey. Accordingly, there are ontogenetic shifts in prey selection (e.g. Guiguer et al. 2002, van der Velden et al. 2012), with larger individuals feeding at higher trophic levels because of increased forage fish consumption. That no such relationship was found in the $S$. trutta from the Drevja and Nidelva Rivers is likely due to the low mean $L_{\mathrm{T}}$ (Drevja) and low number of sampled fish (Nidelva).

Marine parasites were frequent $(67-100 \%)$ on $S$. trutta at all sampled localities, and infection patterns (prevalence and abundance) showed consistency across different habitat types (i.e. fjords and river systems) across the entire geographic region. Parasite species potentially transmitted by fish as prey (i.e. nematodes, cestodes and trematodes) had a much higher prevalence than parasites transmitted by crustaceans (i.e. Acanthocephala), which may be because fish are the main dietary component of $S$. trutta. Also, S. trutta caught in the sea had similar patterns of infection to those individuals caught in the river, suggesting that prevalence of marine parasites is a good indicator of anadromous life-history strategies in general, both at the individual (Knudsen et al. 2011, 2014) and the population level (e.g. MacKenzie \& Abaunza 1998, Knudsen et al. 2005).

Generally, the endoparasites recorded from central Norwegian $S$. trutta had lower abundance compared to those recorded from northern Norway (Knudsen et al. 2011). Parasite infections have been shown to impair swimming performance and lead to decreases in burst swimming speed, migration performance and fatigue distance (Barber \& Poulin 2002). High parasite burdens have also been associated with pale gills, decreased body condition and host mortality in farmed S. trutta (Rubio-Godoy \& Tinsley 2008), with high loads of intestinal helminths in particular seen as the probable trigger for long-term malnutrition leading to increased $S$. trutta emaciation and mortality (Mladineo et al. 2009). High parasite loads may also affect fish behaviour, altering habitat use and foraging opportunity as infected individuals adopt 
movement patterns expected to suppress infestation rates (Gjelland et al. 2014). Lowered levels of parasites observed at sites sampled here suggest reduced parasite-induced energetic and fitness costs for $S$. trutta in central Norway. A possible exception may be those individuals that had relatively high densities of the adult cestode, Eubothrium sp. This genus has been shown to have negative consequences for individuals' somatic growth (Bristow \& Berland 1991, Saksvik et al. 2001).

Examination of stomach contents indicated that small pelagic fish species like sprat Sprattus sprattus, herring Clupea harengus and small sandeel Ammodytes tobianus are important parts of $S$. trutta diets, as has been similarly noted in the studies of Knutsen et al. (2001) and Rikardsen \& Amundsen (2005). Observed trophic niche similarity across sea trout populations over a large geographical area suggests that sea trout may be vulnerable to fluctuations in these prey populations.

In partially anadromous species, marine migrations are not obligate and individual fish may change life history tactics (i.e. anadromy versus freshwater residency) to maximize fitness if environmental conditions change (e.g. Nordeng 1983, Jonsson \& Jonsson 1993). Indeed, anadromy may have evolved in the first place as a response to situations where food resources in the sea exceeded those in freshwater (Gross 1987). Thus, significant decreases in biomass and reduced availability of pelagic prey fish species for larger $S$. trutta may trigger alterations in their feeding behaviour by reduced feeding time at sea and/or shifting diet to a heavier reliance on littoral marine prey, or even a change in life history tactics to feed exclusive on freshwater prey resources.

Other preferred dietary items in addition to the species mentioned above may include fishes of the families Clupeidae and Gobiidae in areas and years when they are abundant (Knutsen et al. 2001, 2004), but these were not observed here. Prey fish species found in this study have generally been subject to wide fluctuations in relative abundance. For example, the biomass of A. tobianus has declined markedly in the last 2 decades (ICES 2015). Likewise, C. harengus experienced a significant decline in abundance in the 1970s (ICES 2015). Fluctuations in the relative abundances of small prey fishes have been correlated with size (mass) of other coastal feeding salmonids such as Salvelinus alpinus (Dempson et al. 2002).

The similarities in marine-captured $S$. trutta diets and stable isotope signatures and the pattern of infection of marine parasites suggests that there is rough equivalence in the foraging niches across $S$. trutta populations along the coastal area of central Norway. Results thus indicate that the marine environment in the actual geographical region has relatively similar diet resources for anadromous salmonid populations. The geographic equivalence of the trophic niche of anadromous $S$. trutta could imply that they are vulnerable to possible future changes in the coastal environments that would affect the densities of favoured marine prey. Thus, the variable density of the marine prey fish species used by $S$. trutta along the coast could explain some of the declines in the recorded densities of sea trout populations that have been observed in recent decades (ICES 2013, Anon. 2015). As $S$. trutta in general appear to depend on pelagic fish species such as $S$. sprattus, C. harengus and $A$. tobianus, special attention needs to be given to the conservation of these species as they represent important prey resources for $S$. trutta.

In conclusion, the large similarity observed in $S$. trutta feeding niches from the 7 localities found using stomach contents combined with 2 time-integrated trophic tracers (trophically transmitted parasites and stable isotopes) suggests that $S$. trutta occupy similar trophic niches at broad regional scales. While it was found that the $S$. trutta have generalist diets at the population level, as individuals they tend to specialize due to size-related feeding preferences. Such specialization may make $S$. trutta vulnerable to anthropogenic ecosystem perturbations (e.g. climate change, overfishing, shoreline development) that may change the diversity of potential marine prey items and thus cause a reduction in their abundance.

Acknowledgements. This study was financed by the County Governor of Sør-Trøndelag, The Royal Norwegian Society of Sciences and Letters, the Norwegian Institute for Nature Research, UiT the Arctic University of Norway, an NSERC Discovery Grant to M.P. and the NTNU University Museum. M. G. Hansen, A. Jørrestol, S. H. Eldøy and A. Sandvik are thanked for their extensive help during the fieldwork and G. Kjærstad for assistance with analysis of the fish. M. Daverdin at the NTNU University Museum is thanked for drawing the map and A. Eloranta for comments on a previous version of the manuscript.

\section{LITERATURE CITED}

Anonymous (2015) Status for norske laksebestander i 2015. Rapport fra Vitenskapelig råd for lakseforvaltning nr 8. Norwegian Scientific Advisory Committee for Atlantic Salmon Management, Trondheim

Barber I, Poulin R (2002) Interactions between fish, parasites and disease. In: Hart PJB, Reynolds JD (eds) Handbook of fish biology and fisheries, Book 1. Blackwell Publishing, Oxford

Bristow GA, Berland B (1991) The effect of long term, low 
level Eubothrium sp. (Cestoda: Pseudophyllidea) infection on growth in farmed salmon (Salmo salar L.). Aquaculture 98:325-330

Bush AO, Lafferty KD, Lotz JM, Shostak AW (1997) Parasitology meets ecology on its own terms: Margolis et al. revisited. J Parasitol 83:575-583

Dempson JB, Shears M, Bloom M (2002) Spatial and temporal variability in the diet of anadromous Arctic charr, Salvelinus alpinus, in northern Labrador. Environ Biol Fishes 64:49-62

Doucett RR, Hooper W, Power G (1999a) Identification of anadromous and non-anadromous adult brook trout (Salvelinus fontinalis) and their progeny in the Tabusintac River, New Brunswick, using multiple stable-isotope analysis. Trans Am Fish Soc 128:278-288

Doucett RR, Power M, Power G, Caron F, Reist JD (1999b) Evidence for anadromy in a southern relict population of Arctic charr from North America. J Fish Biol 55:84-92

Elliott JM (1994) Quantitative ecology and the brown trout. Oxford University Press, Oxford

Elliot JM (1997) Stomach contents of adult sea trout caught in six English rivers. J Fish Biol 50:1129-1132

* Etheridge EC, Harrod C, Bean C, Adams CE (2008) Continuous variation in the pattern of marine v. freshwater foraging in brown trout Salmo trutta L. from Loch Lomond, Scotland. J Fish Biol 73:44-53

Fagan KA, Koops MA, Arts MT, Power M (2011) Assessing the utility of $\mathrm{C}: \mathrm{N}$ ratios for predicting lipid content in fishes. Can J Fish Aquat Sci 68:374-385

Fredriksen S (2003) Food web studies in a Norwegian kelp forest based on stable isotope $\left(\delta^{13} \mathrm{C}\right.$ and $\left.\delta^{15} \mathrm{~N}\right)$ analysis. Mar Ecol Prog Ser 260:71-81

Fry B (2006) Stable isotope ecology. Springer, New York, NY

Gjelland KØ, Serra-Llinares RM, Hedger RD, ArechavalaLopez P and others (2014) Effects of salmon lice infection on the behaviour of sea trout in the marine phase. Aquacult Environ Interact 5:221-233

Grønvik S, Klemetsen A (1987) Marine food and diet overlap of co-occuring Arctic charr (Salvelinus alpinus L.), brown trout (Salmo trutta L.) and Atlantic salmon (S. salar L.) off Senja, N. Norway. Polar Biol 7:173-177

Gross MR (1987) Evolution of diadromy in fishes. In: Dadswell MJ, Klauda RJ, Moffitt CM, Saunders RL, Rulifson RA, Cooper JE (eds) Common strategies of anadromous and catadromous fishes. Am Fish Soc Symp 1, Bethesda, p 14-24

* Gross MR, Coleman RM, McDowall RM (1988) Aquatic productivity and the evolution of diadromous fish migration. Science 239:1291-1293

* Guiguer KRRA, Reist JD, Power M, Babaluk JA (2002) Using stable isotopes to confirm the trophic ecology of Arctic charr morphotypes from Lake Hazen, Nunavut, Canada. J Fish Biol 60:348-362

Hemmingsen W, Mackenzie K (2001) The parasite fauna of the cod, Gadus morhua L. Adv Mar Biol 40:1-80

Hendry AP, Bohlin T, Jonsson B, Berg OK (2004) To sea or not to sea? Anadromy versus non-anadromy in salmonids. In: Hendry AP, Stearns SC (eds) Evolution illuminated: salmon and their relatives. Oxford University Press, New York, NY, p 92-125

Hobson KA, Fisk A, Karnovsky N, Holst M, Gagnon JM, Fortier $M$ (2002) A stable isotope $\left(\delta^{13} C, \delta^{15} N\right)$ model for the North Water food web: implications for evaluating trophodynamics and the flow of energy and contaminants. Deep Sea Res II 49:5131-5150
Hyslop EJ (1980) Stomach contents analysis - a review of methods and their application. J Fish Biol 17:411-429

ICES (2013) Report of the workshop on sea trout (WKTRUTTA), 12-14 November 2013, ICES Headquarters, Copenhagen

ICES (2015) ICES stock assessment database. ICES, Copenhagen. http://ices.dk/marine-data/tools/Pages/ stock-assessment-graphs.aspx

Jackson AL, Parnell AC (2016) Stable Isotope Bayesian Ellipses in R. https://cran.r-project.org/web/packages/ SIBER/SIBER.pdf

* Jardine TD, Hunt RJ, Faggotter SJ, Valdez D, Burford MA, Bunn SE (2013) Carbon from periphyton supports fish biomass in waterholes of a wet-dry tropical river. River Res Appl 29:560-573

Jennings S, Warr KW (2003) Environmental correlates of large-scale spatial variation in the $\delta^{15} \mathrm{~N}$ in marine animals. Mar Biol 142:1131-1140

Jensen H, Kiljunen M, Amundsen PA (2012) Dietary ontogeny and niche shift to piscivory in lacustrine brown trout Salmo trutta revealed by stomach content and stable isotope analyses. J Fish Biol 80:2448-2462

Jonsson B (1985) Life history patterns of freshwater resident and sea-run migrant brown trout in Norway. Trans Am Fish Soc 114:182-194

Jonsson B, Jonsson N (1993) Partial migration: niche shift versus sexual maturation in fishes. Rev Fish Biol Fish 3: 348-365

Klemetsen A, Amundsen PA, Dempson JB, Jonsson B, Jonsson N, O'Connell MF, Mortensen E (2003) Atlantic salmon Salmo salar L., brown trout Salmo trutta L., and Arctic charr Salvelinus alpinus (L.): a review of aspects of their life histories. Ecol Freshwat Fish 12:1-59

Knudsen R, Klemetsen A, Staldvik F (1996) Parasites as indicators of individual feeding specialization in Arctic charr during winter in northern Norway. J Fish Biol 48: 1256-1265

Knudsen R, Rikardsen AH, Dempson JB, Bjørn PA, Finstad B, Holm M, Amundsen PA (2005) Trophically transmitted parasites in wild Atlantic salmon post-smolts from Norwegian fjords. J Fish Biol 66:758-772

Knudsen R, Amundsen PA, Rikardsen AH (2011) Individual feeding specialisation of a naïve vs. veteran predators. Ecol Freshwat Fish 20:522-528

* Knudsen R, Siwertsson A, Adams CE, Newton J, Amundsen PA (2014) Similar patterns of individual niche use are revealed by different time-integrated trophic tracers (stable isotopes and parasites). Ecol Freshwat Fish 23: 259-268

Knutsen JA, Knutsen H, Gjøsæter J, Jonsson B (2001) Food of anadromous brown trout at sea. J Fish Biol 59:533-543

Knutsen JA, Knutsen H, Olsen EM, Jonsson B (2004) Marine feeding of anadromous brown trout (Salmo trutta L.) during winter. J Fish Biol 64:89-99

Lecomte F, Beall E, Chat J, Davaine P, Gaudin P (2013) The complete history of salmonid introductions in the Kerguelen Islands, Southern Ocean. Polar Biol 36:457-475

MacKenzie K, Abaunza P (1998) Parasites as biological tags for stock discrimination of marine fish: a guide to procedures and methods. Fish Res 38:45-56

McKay LR, Gjerde B (1985) The effect of salinity on growth of rainbow trout. Aquaculture 49:325-331

Michener RH, Kaufman L (2007) Stable isotope ratios as tracers in marine food webs: an update. In: Michener RH, Lajtha K (eds) Stable isotopes in ecology and environ- 
mental science. Blackwell, Malden, MA, p 238-282

Mladineo I, Zrnči Z, Orai D (2009) Severe helminthic infection of the wild brown trout (Salmo trutta) in Cetina River, Croatia; Preliminary observation. Bull Eur Assoc Fish Pathol 29:86-91

Nall GH (1930) The life of the sea trout. Seeley, Service and Co., London

Nordeng H (1983) Solution to the 'char problem' based on Arctic char (Salvelinus alpinus) in Norway. Can J Fish Aquat Sci 40:1372-1387

Pemberton R (1976) Sea trout in North Argyll sea lochs. 2. Diet. J Fish Biol 9:195-208

Perga ME, Gerdeaux D (2005) 'Are fish what they eat' all year round? Oecologia 144:598-606

* Phillips DL, Eldridge PM (2006) Estimating the timing of diet shifts using stable isotopes. Oecologia 147:195-203

* Pinnegar JK, Polunin NVC (1999) Differential fractionation of $\delta^{13} \mathrm{C}$ and $\delta^{15} \mathrm{~N}$ among fish tissues: implications for the study of trophic interactions. Funct Ecol 13:225-231

Post DM (2002) Using stable isotopes to estimate trophic position: models, methods, and assumptions. Ecology 83: 703-718

Post DM, Layman CA, Arrington DA, Takimoto G, Quattrochi J, Montana CG (2007) Getting to the fat of the matter: Models, methods and assumptions for dealing with lipids in stable isotope analyses. Oecologia 152:179-189

Power M, Power G, Reist JD, Bajno R (2009) Ecological and genetic differentiation among the Arctic charr of Lake Aigneau, Northern Quebec. Ecol Freshwat Fish 18: 445-460

Renkawitz MD, Sheehan TF, Dixon HJ, Nygaard R (2015) Changing trophic structure and energy dynamics in the Northwest Atlantic: implications for Atlantic salmon feeding at West Greenland. Mar Ecol Prog Ser 538:197-211

Rikardsen AH, Amundsen PA (2005) Pelagic marine feeding of Arctic charr and sea trout. J Fish Biol 66:1163-1166

Rikardsen AH, Dempson JB (2011) Dietary life-support: the food and feeding of Atlantic salmon at sea. In: Aas $\varnothing$, Einum S, Klemetsen A, Skurdal J (eds) Atlantic salmon ecology Wiley-Blackwell, New York, NY, p 115-144

Rikardsen $\mathrm{AH}$, Amundsen PA, Knudsen R, Sandring S (2006) Seasonal marine feeding and body condition of sea trout (Salmo trutta) at its northern distribution. ICES J Mar Sci 63:466-475

Editorial responsibility: Thomas Turner,

Albuquerque, New Mexico, USA
Rikardsen AH, Dempson JB, Amundsen PA, Bjørn PA, Finstad B, Jensen AJ (2007) Temporal variability in marine feeding of sympatric Arctic charr and sea trout. J Fish Biol 70:837-847

Rubio-Godoy M, Tinsley RC (2008) Recruitment and effects of Discocotyle sagittata (Monogenea) infection on farmed trout. Aquaculture 274:15-23

Saksvik M, Nilsen F, Nylund A, Berland B (2001) Effect of marine Eubothrium sp. (Cestoda: Psaudophyllidea) on growth of Atlantic salmon, Salmo salar L. J Fish Dis 24: $111-119$

Sharp Z (2007) Principles of stable isotope geochemistry. Pearson Prentice-Hall, Upper Saddle River, NJ

Søreide JE, Hop H, Carroll ML, Falk-Petersen S, Hegseth EN (2006) Seasonal food web structures and sympagicpelagic coupling in the European Arctic revealed by stable isotopes and a two-source food web model. Prog Oceanogr 71:59-87

Stallings CD, Nelson JA, Rozar KL, Adams CS and others (2015) Effects of preservation methods of muscle tissue from upper-trophic level reef fishes on stable isotope values $\left(\delta^{13} \mathrm{C}\right.$ and $\left.\delta^{15} \mathrm{~N}\right)$. PeerJ 3:e874

Thorstad EB, Todd CD, Uglem I, Bjørn PA and others (2015) Effects of salmon lice Lepeophtheirus salmonis on wild sea trout Salmo trutta-a literature review. Aquacult Environ Interact 7:91-113

* Thorstad EB, Todd CD, Uglem I, Bjorn PA and others (2016) Marine life of the sea trout. Mar Biol 163:47

* Trueman CN, McGill RAR, Guyard PH (2005) The effect of growth rate on tissue-diet isotopic spacing in rapidly growing animals. An experimental study with Atlantic salmon (Salmo salar). Rapid Commun Mass Spectrom 19: 3239-3247

* van der Velden S, Reist JD, Babaluk JA, Power M (2012) Biological and life-history factors affecting total mercury concentrations in Arctic charr from Heintzelman Lake, Ellesmere Island, Nunavut. Sci Total Environ 433: 309-317

Van der Zanden MJ, Rasmussen JB (1999) Primary consumer $\delta^{13} \mathrm{C}$ and $\delta^{15} \mathrm{~N}$ and the trophic position of aquatic consumers. Ecology 80:1395-1404

Wootton RJ (1998) Ecology of teleost fishes. Kluwer Academic, Dordrecht

Zar JH (2009) Biostatistical analysis. Pearson, New York, NY

Submitted: February 7, 2017; Accepted: September 21, 2017

Proofs received from author(s): November 1, 2017 